Article

\title{
The Critical Factors Affecting the Consumer Reselling of Limited Edition Products: A Case in the Korean Fashion Sector
}

\author{
Woodong Kim and Boyoung Kim * \\ Seoul Business School, Seoul School of Integrated Sciences and Technologies (aSSIST), Seoul 03767, Korea; \\ woodong.kim@dae-yeon.co.kr \\ * Correspondence: bykim2@assist.ac.kr; Tel.: +82-70-7012-2728
}

Received: 23 August 2020; Accepted: 3 October 2020; Published: 4 October 2020

\begin{abstract}
Since e-commerce has revitalized recently in the form of live commerce and Instagram shopping, both purchase and sales have become promoted among consumers while reselling has been facilitated in second-hand item markets and among consumers. Particularly, the new trend of consuming products, rather than merely owning products, has become a mainstream factor in the market. Accordingly, consumers show extraordinary consumption, focusing on the act of purchasing limited edition products of high scarcity and placing more importance on one-off experience rather than ordinary new products or premium products. This study suggests critical factors that facilitate the reselling of limited edition products among consumers for the purpose of examining the consumer reselling of limited edition products, which has been a rapidly growing trend in the fashion market. Based on relevant studies, this research presents four basic factor areas: personal needs, value, experience, and environment. It also defines 20 sub-factors and analyzes the weight of each factor by means of the AHP method. In conclusion, it turned out that factors of personal needs were of the most significant influence. Particularly, it was verified that the need for joining was the most critical factor facilitating consumers' reselling of limited edition products.
\end{abstract}

Keywords: consumer reselling; limited edition products; e-commerce; reselling market; AHP

\section{Introduction}

Now that the transition in consumption patterns and distribution channels is accelerating from offline to online due to COVID-19, the market for secondhand articles is growing rapidly. Particularly, the reselling market grows in the fashion industry. According to a U.S. secondhand clothing company named "thredUP," traditional secondhand trades and donations reported an estimated average annual growth rate of 6\% from USD (US Dollar) 21 billion in 2019 to USD 28 billion in 2024. Regarding the reselling market, in contrast, the average annual growth rate is estimated to be $36 \%$ from USD 7 billion in 2019 to USD 36 billion in 2024. In addition to this, it is expected that, by 2029, the market scale of fast fashion will exceed USD 43 billion and reach USD 44 billion. In the market of sneaker reselling, where teenagers and 20s people are the main market participants, the market scale is expected to increase from USD 2 billion in 2019 to USD 6 billion by 2025 [1].

Against this background, the market for limited edition product reselling is revitalized in line with the consumer sentiment of pursuing "my own" [2]. Limited edition reselling is an act of selling and buying goods of scarcity. People may gain profit from selling goods at a price higher than the original price to prospective consumers when the goods become scarcer over time [3]. In order to buy limited edition products, consumers are willing to stand in line even overnight when the release date gets nearer. The general public, who are consumers and sellers at the same time, may register 
their reselling goods on an online reselling platform or upload products onto their personal SNS (social network service), communicating and trading in such ways as exchanging comments and direct messages (DMs). The combination of needs for goods of high scarcity, consumers' active utilization of various distribution platforms for transactions, and the growth of the secondhand goods markets is catalyzing the revitalization of limited edition reselling markets based on Customer to Customer (C2C) transactions [4].

$\mathrm{Chu}$ and Liao [5] point out that consumers view scarce goods as of higher quality regardless of the actual quality. Many other studies [6-8] also verify that, in general, scarcity messages effectively arouse purchase intentions among potential consumers and result in positive and direct effects on brand values. While the limited edition reselling market has centered on certain groups seeking vintage furniture and art toys (such as figures), the range has expanded recently to cover, for example, the Galaxy Z Flip Tom Brown edition of Samsung Electronics, Nintendo Switch, Nike Off-White, and so forth.

In general, the marketing strategy of business entities to limit availability is an approach to cause consumers, who hesitate to buy, to regret their decision not to buy in the present [9]. Going beyond the level of limited edition marketing, the consumption and sales of limited edition reselling products are related to viral marketing based on the combined dispositions of consumers. They want to purchase goods of high scarcity, to share such goods through the reselling process, and to make known their sense of superiority [10]. As suggested by Jang et al. [11], the concept of consumer reselling expands the concept of the consumer decision process in the framework of traditional consumer behavior theories. Particularly, "Live Commerce" is expanding based on YouTube channels such as VINCE LIVE and Saucelive, whereas "Instagram Commerce" brands are increasing mainly due to influencers such as Kim Kardashian and Kylie Jenner. In the research of Zhang and Zhang [12], about $46 \%$ of the respondents to the survey on Facebook users answered that they often purchased products or services from C2C Facebook Group. Logging into a C2C platform has become a part of the behavioral consumption pattern of young consumers. The traditional concept of buying and selling as consumers is no longer practical in the current market conditions [13-15].

Because the traditional boundary has dissolved in the face of such new market environments and consumer behaviors, the consumers' reselling behavior has become far more active. In addition, the reselling of limited edition products will continue in order to fulfill the needs for goods of scarcity [16]. Nevertheless, most previous studies focused on consumer attitudes in relation to the peculiarity of limited edition products or differences from existing distribution networks in the context of C2C transactions [17]. Accordingly, the objective of this study is to derive and present major factors affecting consumers in the reselling market of limited edition fashion products. By examining the characteristics of and influential factors in consumption behaviors as regards limited edition product reselling, this study presents specific significances for better understanding of the market where the boundary between purchasing and selling is dissolved, as well as consumer behaviors in the changing consumption environments.

\section{Literature Review}

\subsection{Social Commerce and Customer Reselling}

Reselling markets are growing at various SNS-based distribution channels and have developed on the basis of technological advancement [18]. Person to person (PtoP) methods, which connect potential buyers seeking and trading products directly with sellers, have become familiar to consumers [19]. Particularly, professional resellers tend to resell previous versions of products online in reflection of the common characteristics of consistent needs for upgraded products in order to make up for some of the purchase expenses and then buy more new products. Innovators and early adopters who pursue the latest products constantly are more highly motivated to resell previous versions [20]. Some of the financial costs for new products are recovered by reselling old products in one's possession, which are 
sold mostly at higher prices [21]. Out of psychological inclination to avoid waste, individuals prefer selling old products at a price higher than the original before purchasing a new product [22,23].

In view of the consumption environments of the general public in addition to such professional resellers, the supersaturation of brands, excessive competition, and advancement of production technology in the market lead to the releasing of new products one after another at a high pace. Accordingly, the cycle for the general public to buy and possess products has also been shortened. As a result, purchase behaviors for one-time experience of goods are promoted. The general consumption pattern is to focus on purchasing new products by reselling owned goods rather than keeping them permanently [24].

As consuming product experiences and messages rather than merely pursuing the value of owning and using products becomes an evident phenomenon, consumers strongly appeal, in their consuming behaviors, the need for differentiated experiences by purchasing products of high scarcity rather than mere new products or premium products. It has become a general trend that when limited edition products or upgraded new products are not available in ordinary distribution channels, consumers satisfy their consumption needs through a reselling market.

Certain commodities are utilized as tokens to assert an individual's social status indirectly to others [25-27] or to express their uniqueness to acquaintances or companions [28-31]. As someone uses the same goods with a certain group, he or she develops a sense of belonging or unity to that group. For goods to function as a symbol of social status, as a means to express one's uniqueness, or as a way to express one's unity to a certain group, the goods need to be available, not to everyone, but only to a limited number of people [32].

\subsection{Consumer Reselling of Limited Edition Products}

Accordingly, the global reselling market of limited edition products is growing rapidly [33,34]. In this study, such consumption behavior is referred to as "extraordinary consumption behavior." The term "extraordinary" indicates that such experience is neither ordinary nor part of the daily routine of one's life. While "ordinary" indicates that the experience is common and frequent in daily life, "extraordinary" indicates that the experience is not common but rarely occurs and is not part of the daily routine [35]. In existing fields of consumer behavior research, the concept of "extraordinary" is applied to a wide scope, from tangible products to intangible services or experiences, because "ordinary" and "extraordinary" are of a continuum that combines routine events of high "frequency" and exceptional situations of low "frequency" in series [36].

In other words, as "a small number of unique experiences" are popularized in a consumer trend, they are no longer an "extraordinary consumption behavior" but part of a "routine." In qualitative research of consumer behavior, an extraordinary consumption experience is an intense, joyful, unique, and playful activity involving changes [37]. Such an experience is also an anti-structure activity to escape from the modern society; that is, it is a diversion from routine stress, rationality, and rules [38] since "extraordinary consumption behavior" is of an anti-structure nature in the social context. A low level of conception of economic mobility indicates that one views the possibility of transitioning from one's current economic class to an upper class as low. In other words, the individual hardly determines happiness at his/her own discretion or will due to a kind of suppressed and restricted condition.

According to $\mathrm{Ku}$ et al. [39], who examined the significant effect of scarcity messages on the decision-making behavior of consumers, scarcity messages had positive effects on intention of purchase. When the discount rate was high and the level of cognitive motivation was low, the effect was more significant. Jones et al. [40] suggested that, in general, people are reluctant to buy goods that are already used by too many similar people. Because of their social desire, expression of personality, or adherence to a certain quality, consumers intending to use special edition products are more attracted to and are likely to buy limited edition products rather than products available only for a limited period but with no quantitative limit [41]. When it comes to limited edition products, the limitation in time and quantity is the decisive factor that develops the market of purchase and sales among customers, 
which enterprises themselves, in fact, cannot plan or provide. In addition, sales learning and behavior are induced among active consumers with a strong desire to purchase. This further promotes the act of reselling, which involves both the purchase and sale of products [42].

This study, therefore, assumes that, under such restrictive situations, consumers are more inclined to pursue extraordinary consumption behavior [43]. After all, modern day consumers are in search of uniqueness and prefer goods hardly available. People tend to value properties of scarcity more than those highly available [44]. Such a scarcity effect is based on the perceived, subjective desirableness of a certain object [45]. The fact that the possibility of product purchase is limited causes psychological suppression upon consumers and increases their desire to buy the particular item. Messages designed for this purpose are called scarcity messages [46].

\subsection{The Effect Factors of Limited Edition Product Reselling}

Scarcity affects the availability of products, making less common products perceived as more valuable [47]. In other words, scarcity messages are one communication method to increase the value and desirableness of a certain product based on the fact that its availability is limited. Many previous studies in common pointed out that scarcity messages had a powerful persuasive effect [48]. Specifically, the perception of scarcity induces a kind of excitement and tension to consumers, developing an urgent need for such products among them. Scarcity messages also affect consumers' perception of product values and intention of purchase directly [49].

Particularly, many enjoy revealing their tastes and personalities by owning limited edition products with the values of possessing and scarcity. As this "reselling culture" develops, resellers who purchase products of scarcity for selling and then reselling purposes are drawing attention [50]. Since resellers purchase from distributors and sell goods for profit-making purposes, opportunities for consumers to purchase such goods at a fixed price are limited. Thus, ordinary consumers interested in buying goods have to bear with monetary sacrifice because they pay more even though they know the regular price [51]. In the reselling market of such limited edition products, therefore, consumers often play roles as both the purchaser and seller [52]. For this reason, consumers' act of making decisions on buying goods cannot be defined on the basis of traditional roles. Rather, it is necessary to understand the general behavior of consumers regarding the reason why consumers purchase and resell limited edition products.

According to previous studies, factors affecting the act of buying limited edition products can be explained by values and empirical factors discussed in the commodity theory, with the influence of scarcity and possessiveness also being referred to in the context of the "need for uniqueness" theory [11]. When it comes to limited edition product reselling, although there has been little research of empirical verification, such factors are explained in the context of appealing financial values such as "resell tech" based on phenomena in the market [53] or in terms of concerted practice or cultural behavior of the young generation following trends led by a unique group [54].

Accordingly, this study examines affecting factors in four basic aspects-need, value, experience, and environment - based on previous studies regarding limited edition purchase and reselling. First, limited edition product reselling by consumers is affected by personal needs. While enterprises' product sales aim mainly at profit-making, consumers do not necessarily aim at financial benefits when deciding to resell purchased goods [55]. Furthermore, previous studies state that buying products of scarcity is done out of need for uniqueness. In order to differentiate themselves from others, people tend to buy products of scarcity that will strengthen their self-image and social image [56]. In addition to the need for uniqueness, however, consumers who purchase and resell limited edition products may practice limited edition product reselling in order to fulfill their personal needs [12,57]. Hence, it is necessary to take into consideration personal psychological needs that affect consumers' act of selling. Based on the self-determination theory [58], this study explains selling motivation with the following factors as the fundamental elements relevant to consumers' reselling of limited edition products: autonomy (to making decisions based on one's own will); competence (the belief to achieve 
a certain intended result); and relatedness (to develop a sense of belonging by forming relationships with others). Additionally, consumers' reselling of limited edition products is examined based on the theories of basic human needs, such as possession, emotion, recognition, and participation [59,60].

Second, value factors that consumers perceive regarding reselling also may be taken into consideration. In general, perceived values are viewed as factors determining consumers' act of purchase [61]. Accordingly, previous studies define value factors perceived by consumers as social value, empirical value, financial value, intellectual value, emotional value, and so forth [62]. Consumers not only make decisions on purchase for the possession or use of products and services but also practice acts of consumption to obtain various value factors such as maintaining relationships, donation, pleasure, etc. In this perspective, the act of limited edition product reselling may likewise be practiced by consumers for the purpose of pursuing certain values in product buying and selling [63].

Third, consumers' act of reselling may be interpreted as a product selling experience not of an enterprise or producer but of a certain individual. Hence, it is necessary to examine the effect of empirical factors on behaviors. Previous studies relate that consumers' empirical values of certain brands or products affect their acts of purchase [64]. Emphasizing experience marketing, Soscia [65] defines sensitivity, emotion, cognitive behavior, and relationship as components of such experience. Other previous studies relate components of consumer experience in various ways [66-68], based on which this study examines the effect of experience factors on resellers when consumers' reselling behavior is viewed in an empirical perspective with limited edition products as a medium.

Fourth, consumers' reselling practice is affected by environments. Above all, reselling in a consumer-to-consumer market is promoted when supported by relevant technological environments such as SNS or transaction platforms [69]. In addition, the market environment needs to stimulate trustworthy relations and transactions among consumers [70,71]. In this perspective, factors affecting stimulation of reselling transactions can facilitate reselling further. In view of previous studies on dynamic environments for market transaction stimulation and business growth $[12,18]$, the main environmental factors affecting business activity include technology, economics/business management, culture, society, interested persons, ecosystem, and institution, among others. Accordingly, this study also examines whether such an environment variable can affect consumers' reselling behavior [64,72,73].

\section{Research Methods}

\subsection{Analytic Hierarchy Porcess (AHP)}

The Analytic Hierarchy Process (AHP) is a method to make a choice when multiple purposes are important to the decision maker. It is possible to assess the weight of each option and solve complicated matters by quantifying comparative elements of available options and performing subjective evaluations. This method assists decision making to support a systematic evaluation of mutually exclusive options when goals or assessment criteria of decision making are multiple and complex. It is possible to clarify attributes of a matter by means of this method in a systematic and hierarchical manner for standardization [74].

In the early 1970s, Professor Thomas Saaty developed this method with the aim of addressing the inefficient decision-making process while cooperating with game theory specialists [75]. This methodology is to analyze the knowledge, experience, and intuition of the conducting a pairwise comparison among elements that constitute the decision-making hierarchy. It is widely utilized in deriving key factors, determining policy options, and establishing strategies [76]. The application of Saaty's AHP has some shortcomings as follows (Saaty, 1998): (1) the AHP method is mainly used in nearly crisp decision applications, (2) the AHP method creates and deals with a very unbalanced scale of judgment, (3) the AHP method does not take into account the uncertainty associated with the mapping of one's judgment to a number, (4) the ranking of the AHP method is rather imprecise, (5) the subjective judgment, selection, and preference of decision makers have great influence on the 
AHP results. In addition, a decision maker's requirements on evaluating alternatives always contain ambiguity and multiplicity of meaning [77].

The AHP methodology is used to derive evaluation results in a form of prioritization among elements of each evaluator [78]. In the previous studies about customer behaviors, Liu and Shih [79] used the AHP method to provide the critical factors of a customer's product recommendation. Chan et al. [80] suggested rating the importance of customer needs in quality function deployment through the fuzzy AHP method. Kabir and Hasin [81] and Kumar et al. [82] measured effective factors of the customer preference and requirements by AHP method. Accordingly, this study utilizes the AHP in order to determine the relative importance of critical factors that affect the customer's reselling of limited edition fashion products.

The "geometric mean of pairwise comparison" is one of the two AHP analysis approaches [83] that is more widely used. The relative importance of each factor is analyzed based on the respective geometric average in this study and by means of this approach. In order to secure the reliability of the analysis and the results of the input variables, the corresponding weight is set in consideration of probabilistic characteristics for the determination of the difference between the input variables and output variable settings of the model. The analysis is conducted on the basis of the AHP variable weight determination method proposed by Yoo \& Kim [84].

\subsection{Figures, Tables and Schemes}

Based on the relevant previous studies, this study examines "personal needs," "value" "experience" and "environment" as factors affecting consumers' limited edition product reselling for comparative analysis. "Personal needs" are personal motivation factors that induce the reselling of limited edition products, including joining, conspicuousness, differentiation, cognition, and self-development. "Value" refers to the factors affecting the values perceived by consumers regarding reselling, including rarity value, financial value, functional value, emotional value, and conditional value. "Experience" indicates the effect of the experience of limited edition products reselling on consumers, specifically including ludic experience, social experience, aesthetic experience, symbolic experience, and various experiences. Finally, "environment" indicates the environmental elements affecting consumers' reselling of limited edition products, including technological condition change, business condition change, inter-personal influence, development of social acceptance, and development of cultural variety (see Figure 1).

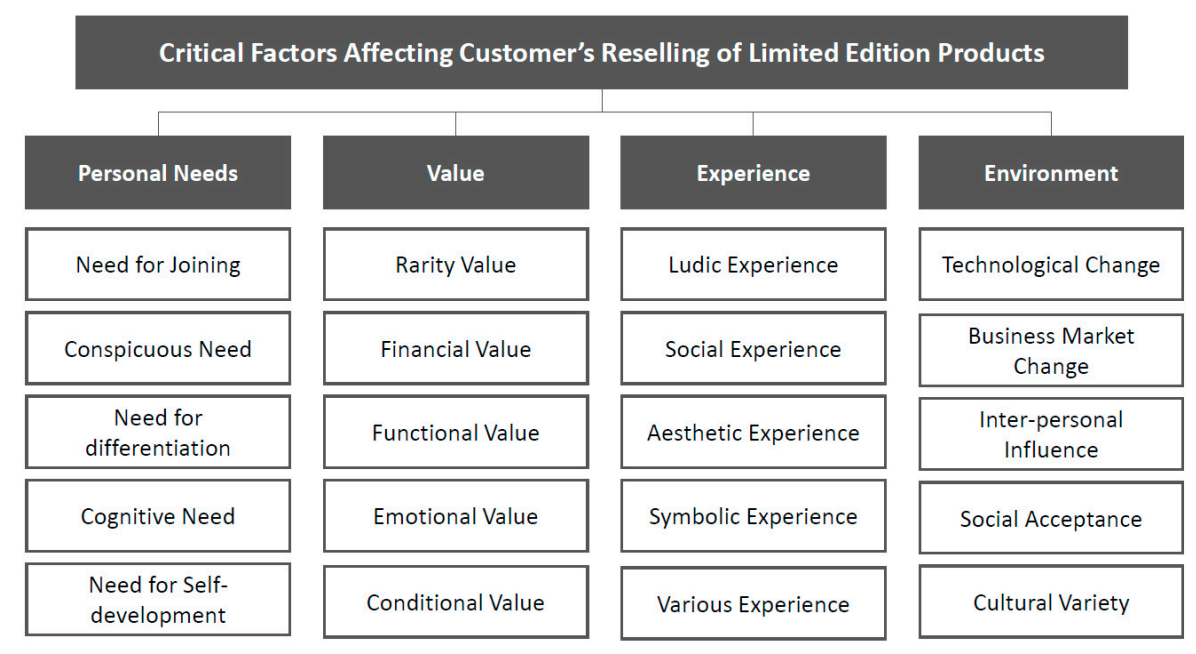

Figure 1. Research model.

These four key variables include 20 components in total (see Table 1). First of all, "Personal needs" includes the following subfactors based on the previous study of Gierl and Huettl [33], $\mathrm{Ku}$ et al. [39], Jones et al. [40], Subramanian and Stock [57], and Swami and Khairnar [59]: need for joining, conspicuous need, need for differentiation, cognitive need, and need for self-development. 
"Value" includes the five following subfactors based on the study of Ramzi et al. [61], Sinha and Verma [62], and Gallarza and Saura [63]: "rarity value," "financial value," "functional value," "emotional value," and "conditional value." "Experience" includes the following subfactors based on the study of Yuan and Wu [66] and Tsai [67]: ludic experience, social experience, aesthetic experience, symbolic experience, and various experience. Finally, "Environment" includes the following subfactors based on the study of Lin and Li [15], Cheema and Kaikati [19], Byun and Sternquist [41], Hollebeek [64], and Yang et al. [70]: technological change, business market change, inter-personal influence, social acceptance, and cultural variety.

Table 1. Evaluation factors and definition.

\begin{tabular}{|c|c|c|c|}
\hline Evaluation Area & Evaluation Factors & Factor Definition & Related References \\
\hline \multirow{3}{*}{ Personal needs } & Need for joining & $\begin{array}{l}\text { Need to practice participating and empathizing } \\
\text { through reselling }\end{array}$ & \multirow{3}{*}{$\begin{array}{c}\text { Gierl and Huettl [33] } \\
\text { Ku et al. [39] } \\
\text { Jones et al. [40] } \\
\text { Subramanian and Stock [57] } \\
\text { Swami and Khairnar [59] }\end{array}$} \\
\hline & Need for differentiation & $\begin{array}{l}\text { Need to differentiate oneself from others and pursue } \\
\text { uniqueness through reselling }\end{array}$ & \\
\hline & $\begin{array}{c}\text { Need for } \\
\text { self-development }\end{array}$ & Need to realize self-development through reselling & \\
\hline \multirow{4}{*}{ Value } & Rarity value & $\begin{array}{l}\text { Value of buying and selling limited edition products or } \\
\text { rare products through reselling }\end{array}$ & \multirow{4}{*}{$\begin{array}{l}\text { Ramzi et al. [61] } \\
\text { Sinha and Verma [62] } \\
\text { Gallarza and Saura [63] }\end{array}$} \\
\hline & Financial value & $\begin{array}{c}\text { Value of making financial profits by purchasing } \\
\text { products at a low price or selling at a high price } \\
\text { through reselling }\end{array}$ & \\
\hline & Emotional value & $\begin{array}{l}\text { Value of enjoying emotional satisfaction, joy, and a } \\
\text { sense of comfort through reselling }\end{array}$ & \\
\hline & Conditional value & $\begin{array}{c}\text { Value of adjusting product buying and selling in line } \\
\text { with one's own condition and convenience } \\
\text { through reselling }\end{array}$ & \\
\hline \multirow{2}{*}{ Experience } & Ludic experience & $\begin{array}{l}\text { Ludic and delightful satisfaction with } \\
\text { reselling experience }\end{array}$ & \multirow{2}{*}{$\begin{array}{l}\text { Yuan and } \mathrm{Wu}[66] \\
\text { Tsai [67] }\end{array}$} \\
\hline & Social experience & $\begin{array}{l}\text { Satisfaction with reselling experience such as a sense of } \\
\text { superiority and a fulfilled desire for power }\end{array}$ & \\
\hline \multirow{5}{*}{ Environment } & Technological change & $\begin{array}{l}\text { Effect of technical elements such as reselling platform } \\
\text { advancement and technical convenience }\end{array}$ & \multirow{5}{*}{$\begin{array}{l}\text { Lin and Li [15] } \\
\text { Cheema and Kaikati [19] } \\
\text { Byun and Sternquist [41] } \\
\text { Hollebeek [64] } \\
\text { Yang et al. [70] }\end{array}$} \\
\hline & Business market change & $\begin{array}{l}\text { Effect of the variety of market and business types in } \\
\text { terms of reselling }\end{array}$ & \\
\hline & Inter-personal influence & $\begin{array}{l}\text { Effect of acquaintances' recommendations and } \\
\text { communities regarding reselling }\end{array}$ & \\
\hline & Social acceptance & $\begin{array}{l}\text { Effect of society-receptive elements such as necessity } \\
\text { and generalization in the society regarding reselling }\end{array}$ & \\
\hline & Cultural variety & $\begin{array}{l}\text { Effect of cultural aspects such as cultural feedback and } \\
\text { popularity regarding reselling }\end{array}$ & \\
\hline
\end{tabular}

\subsection{Research Process and Data Collection}

This study utilizes a pairwise comparison questionnaire for AHP methodology application on the basis of the research framework illustrated in Figure 1 in order to analyze factors affecting consumers' behavior on limited edition product reselling. The questionnaire consists of 47 questions in total: 
1 subjective question and 46 multiple-choice questions designed for pairwise comparison. A pilot test was conducted among 7 corporate markets and resellers in a market of limited edition product reselling.

Survey participants were selected from an expert group with a deep understanding of the limited edition reselling market, limited edition product reselling, and marketing activity performances in the Korean reselling market. In addition, a reselling group was organized to create a survey with professionals operating a reselling start-up or reselling limited edition products regularly. In consideration of professionalism and experience, those with a career in the relevant area for at least 5 years were selected as survey participants. This survey with interviews was conducted for 2 months from the middle of May to the middle of July 2020 in South Korea. For each participant, the background of this survey and variable definitions were explained for about 1 hour for their full understanding, and they were helped with the detailed guideline of researchers to answer questions in the questionnaire. Finally, 30 copies of the questionnaire were collected from 15 professionals and 15 resellers. With 4 copies with insignificant contents excluded among these, 26 questionnaires including 13 from each group were used in the final step.

Table 2 shows the demographic information of respondents. First of all, 77\% were male respondents and $23 \%$ were female. In total, $15.4 \%$ were in their $20 \mathrm{~s}, 65.4 \%$ in their 3 The , and $65.4 \%$ in their 40 s. A total of $26.9 \%$ had 5 to 10 years of work experience in the reselling market, and another $26.9 \%$ had 10 to 15 years. Those with 15 years of experience accounted for the largest portion, $46.2 \%$. MS Excel program was used for data analysis. In order to secure the reliability of survey results, the comparison performer's consistency ratio (CR) was calculated. As a result, the CR was all under 1 -between 0.1494 and 0.5172 - which indicates that the values were significant.

Table 2. Demography information.

\begin{tabular}{cccc}
\hline \multirow{2}{*}{ Characteristics } & & Frequency & Ratio (\%) \\
\hline \multirow{3}{*}{ Gender } & Male & 20 & 77.0 \\
\cline { 2 - 4 } & Female & 6 & 23.0 \\
\cline { 2 - 4 } & Total & 26 & 100 \\
\cline { 2 - 4 } Age & 20s & 4 & 15.4 \\
\cline { 2 - 4 } & 30s & 17 & 65.4 \\
\cline { 2 - 4 } & 40s & 5 & 19.2 \\
\cline { 2 - 4 } Work Experience in the Media & Total & 26 & 100 \\
\cline { 2 - 4 } & 5-10 years & 7 & 26.9 \\
\cline { 2 - 4 } & 10-15 years & 7 & 26.9 \\
\cline { 2 - 4 } & Over 15 years & 12 & 46.2 \\
\cline { 2 - 4 } Professional Area & Total & 26 & 100 \\
\hline & Export Group & 13 & 50.0 \\
\cline { 2 - 4 } & Reseller Group & 13 & 50.0 \\
\cline { 2 - 4 } & Total & 26 & 100 \\
\hline
\end{tabular}

\section{Results}

\subsection{Comparison of Evaluation Variables}

As shown in Table 3, four key evaluation areas affecting limited edition product reselling were analyzed and, as a result, it turned out that personal needs (0.560) were the most influential, and then value (0.273), experience (0.114), and environment (0.053), in order. It turned out that consumers practiced the reselling of limited edition products mainly due to personal needs rather than due to environment. 
Table 3. Weights of evaluation variables.

\begin{tabular}{|c|c|c|c|c|c|}
\hline \multirow{2}{*}{ Evaluation Areas } & \multirow{2}{*}{ Evaluation Factors } & \multicolumn{4}{|c|}{ The Weights of Evaluation Factors } \\
\hline & & Local * & Priority & Global ** & Priority \\
\hline \multirow{5}{*}{ Personal needs } & Need for joining & 0.444 & 1 & 0.249 & 1 \\
\hline & Conspicuous need & 0.092 & 4 & 0.052 & 6 \\
\hline & Need for differentiation & 0.063 & 5 & 0.036 & 9 \\
\hline & Cognitive need & 0.232 & 2 & 0.130 & 2 \\
\hline & Need for self-development & 0.168 & 3 & 0.094 & 4 \\
\hline \multirow{5}{*}{ Value } & Rarity value & 0.110 & 4 & 0.030 & 10 \\
\hline & Financial value & 0.058 & 5 & 0.016 & 14 \\
\hline & Functional value & 0.437 & 1 & 0.119 & 3 \\
\hline & Emotional value & 0.256 & 2 & 0.070 & 5 \\
\hline & Conditional value & 0.139 & 3 & 0.038 & 8 \\
\hline \multirow{5}{*}{ Experience } & Ludic experience & 0.375 & 1 & 0.043 & 7 \\
\hline & Social experience & 0.127 & 4 & 0.014 & 15 \\
\hline & Aesthetic experience & 0.242 & 2 & 0.028 & 11 \\
\hline & Symbolic experience & 0.200 & 3 & 0.023 & 13 \\
\hline & Various experience & 0.056 & 5 & 0.006 & 18 \\
\hline \multirow{5}{*}{ Environment } & Technological change & 0.232 & 2 & 0.012 & 16 \\
\hline & Business market change & 0.053 & 5 & 0.003 & 20 \\
\hline & Inter-personal influence & 0.449 & 1 & 0.024 & 12 \\
\hline & Social acceptance & 0.162 & 3 & 0.009 & 17 \\
\hline & Cultural variety & 0.103 & 4 & 0.005 & 19 \\
\hline Total & & 4.000 & & 1.000 & \\
\hline
\end{tabular}

* Local: mean value of evaluation factors in each group of criteria. ${ }^{* *}$ Global: mean value of evaluation factors in total criteria.

In view of the analysis results in each area, with regard to the area of personal needs, the need for joining (0.444) and cognitive need (0.232) were the most significant factors, and then the need for self-development (0.168), conspicuous need (0.092), and the need for differentiation (0.063), in order. With regard to the value area, the functional value $(0.437)$ and emotional value $(0.256)$ were most emphasized, followed by the conditional value (0.139), rarity value $(0.110)$, and financial value $(0.058)$. With regard to the experience area, ludic experience (0375), aesthetic experience (0.242), and symbolic experience (0.2000) turned out to be critical factors. Finally, with regard to the environment area, inter-personal influence (0.449) and technological change (0.232) were most influential while the effects of social acceptance (0.162), cultural variety (0.103), and business market change (0.053) were insignificant.

The following is the general priority of 20 subfactors: factors most influential on consumers' reselling of limited edition products turned out to be the need for joining (0.249), cognitive need (0.130), and the need for self-development (0.094). This indicates that consumers practiced the reselling of limited edition products because they sought to satisfy their needs to emphasize others' behaviors and to gain knowledge. Next to these factors, the functional value (0.119), need for self-development (0.094), and emotional value (0.070) also turned out to be of high importance. As these factors were subjective and personal, it turned out that reselling was motivated by highly personal needs and necessity rather than business or economic activities. 


\subsection{Comparison of Evaluation Areas between Expert and Reseller Groups}

When the expert group and the reseller group were compared, their analysis results were the same. As shown in Table 4, major factors of the expert group were factors of personal needs (0.513), value (0.309), experience (0.122), and environment (0.057) in order. In the case of the reseller group as well, the major factors were personal needs (0.577), value (0.263), experience (0.110), and environment $(0.050)$ in order. This indicates that the two groups presented the same opinion.

Table 4. Comparison analysis result on evaluation areas.

\begin{tabular}{ccccc}
\hline \multirow{2}{*}{ Evaluation Areas } & \multicolumn{4}{c}{ The Weights of Areas } \\
\cline { 2 - 5 } & \multicolumn{2}{c}{ Expert Group } & \multicolumn{2}{c}{ Reseller Group } \\
\cline { 2 - 5 } & Local & Priority & Local & Priority \\
\hline Personal needs & 0.513 & 1 & 0.577 & 1 \\
\hline Value & 0.309 & 2 & 0.263 & 2 \\
\hline Experience & 0.122 & 3 & 0.110 & 3 \\
\hline Environment & 0.057 & 4 & 0.050 & 4 \\
\hline Total & 1.0000 & & 1.0000 & \\
\hline
\end{tabular}

\subsection{Comparison of Evaluation Factors between Expert and Reseller Groups}

As subfactors of the two groups were analyzed comparatively (see Table 5), it turned out that, in both groups, the most important factor affecting the act of reselling limited edition products was the "need for joining." With the top five critical factors compared, elements emphasized in the expert group were the need for joining (0.239), functional value (0.131), cognitive need (0.104), need for self-development (0.080), and emotional value (0.080), which indicates the importance of functional values. In the reseller group, the critical factors were the need for joining $(0.247)$, cognitive need (0.149), functional value (0.116), the need for self-development (0.078), and emotional value (0.066), which implies that cognitive needs were emphasized. In the result of subfactor analysis, in which there was little difference in opinions between the two groups, experts put more importance on the functional value in consumers' reselling of limited edition products while resellers who themselves practiced reselling put more importance on the cognitive need when it came to limited edition product reselling. 
Table 5. Comparison analysis result on evaluation factors.

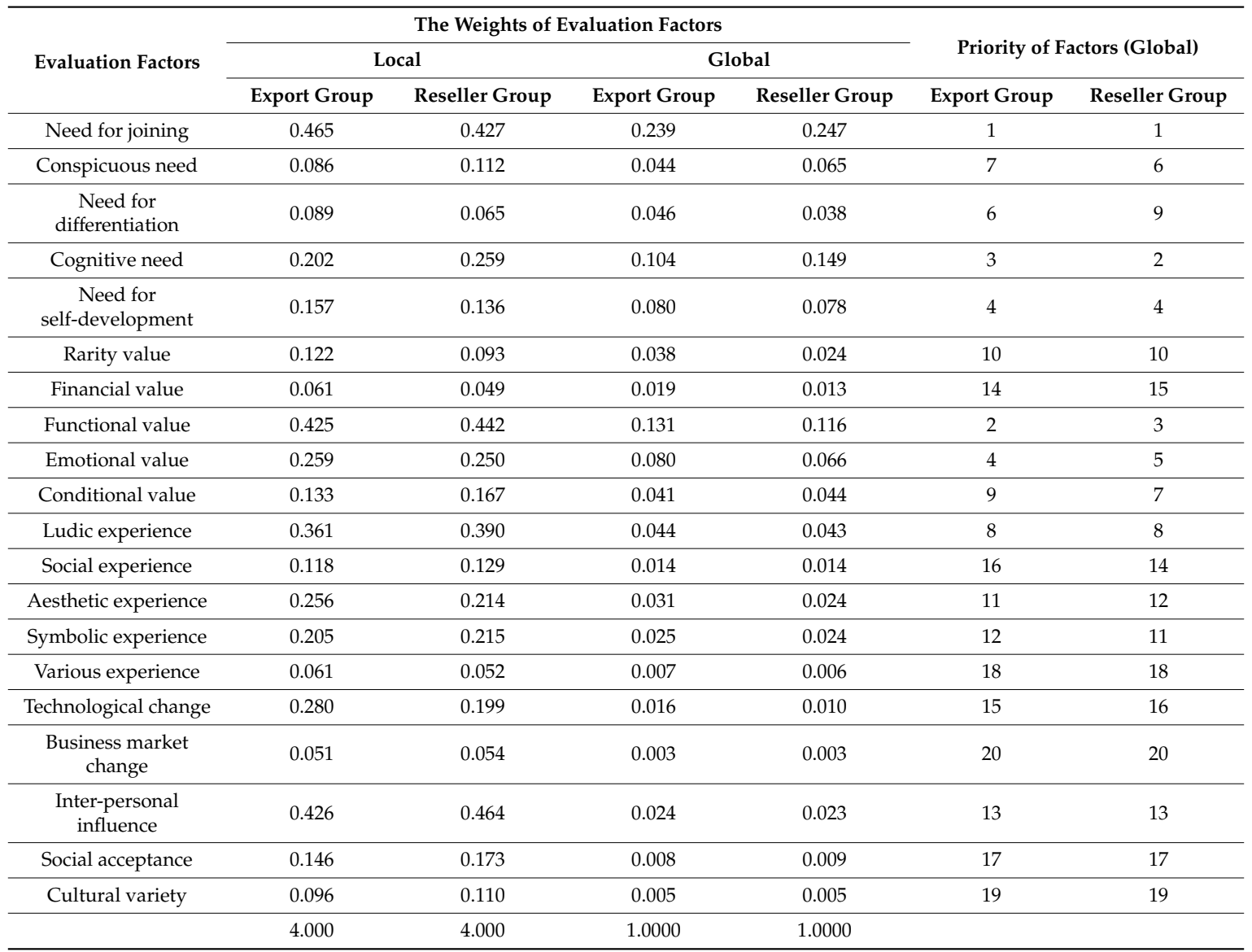

\section{Discussion and Conclusions}

This study analyzes the factors motivating consumers to practice the reselling of limited edition products. In the market of limited edition product reselling, deals are completed with a premium decided on the basis of scarcity. Although some limited edition products are resold after being used for a while, most items are sold with a premium right after the consumer buys them. Deals are done among individuals perceiving the value of scarcity. Accordingly, this study examined the important efficient factors affecting the customer's limited edition reselling attribute by the AHP method. AHP covers the portfolio decisions of a firm and managers with the determination of the desired target portfolio and allocation of resources among its components. The results from the AHP analysis should be helpful for the determination of the directions on new product development and marketing strategy generation among customers, as well as on reselling market management.

\subsection{Findings}

The following are the major results of the analysis: First, it turned out that, when it comes to limited edition product reselling, aspects of personal needs were of significant importance. Currently, major participants in the reselling market are teenagers who put considerable emphasis on personal satisfaction and act freely online. As their lifestyle was considered, aspects of personal needs were most emphasized in the reselling market, specifically their participation, cognitive, and self-development needs, rather than their need to be unique and conspicuous. This result suggests that, when it comes to purchasing and reselling limited edition products, values and empirical factors might be influential but the most important goal is to satisfy the consumers' personal needs. As mentioned in many previous studies, the will to purchase limited edition products is revealed among consumers who are in need for such elements as scarcity, social status, and superiority $[5,85]$. In this regard, the reselling of 
limited edition products is different from that of ordinary, price-dominated secondhand items that are no longer necessary and are traded at low prices. The most dominant factor in the former case is consumers' need for scarcity value, which in fact motivates them to buy and sell [11,16].

Second, among 20 subfactors facilitating the act of reselling, the need for joining turned out to be the most critical factor. This result reflects the unique characteristics of the market of limited edition product reselling where reselling is practiced mainly through online communities and consumers who can both buy and sell limited edition products from such communities. In line with this nature of the market, the need to join in such community activities leads to reselling. In addition, while new job types such as YouTuber, creator, and influencer draw attention as objects of envy among young people, curiosity about communities of limited edition product reselling and the need to participate in them lead consumers to act $[23,33]$.

Third, the growth of the reselling market and the emergence of resellers were closely related to its nature that limited edition products are purchased and resold with a premium. However, the financial value turned out to be of low importance compared to other motivating factors of the reselling market because a small number of resellers manage limited edition products in a business form, cornering and hoarding, while some consumers tend to purchase limited edition products of high scarcity from the reselling market in order to satisfy their personal needs. In other words, the financial value contributed to the growth of the reselling market to some extent, but the premium added to the reselling price turned out to be of low importance in terms of motive power to the reselling market.

\subsection{Managerial Implications}

Based on the findings stated above, the following practical implications are proposed for relevant businesses and marketing professionals: First, to develop brand strategies for the revitalization of the limited edition product market, as well as its marketing activity, it is necessary to stimulate consumers' personal needs. Particularly, marketing strategies may attempt to induce not only purchasing but also reselling among independent consumers so that their need for joining the market is stimulated. For example, interactive communication between influencers and consumers needs to be induced rather than SNS-based, one-way communication led by influencers only [51,86]. When a marketing strategy is established, therefore, it is necessary to form an online community for limited edition products, present detailed stories of each product, and promote free posting and sharing of influencers' honest opinions with consumers, including the photos and comments of the consumers using the products.

Second, it is necessary to develop programs through which product information is shared and consumer experience of limited edition products is built up through offline gatherings of reselling market participants. Enterprises tend to focus on online strategies for cost saving and more efficient exposure to consumers. From a long-term perspective, however, it is advantageous to invest in offline promotion and form loyal consumers of brands and limited edition product categories in order to facilitate a sustainable marketing strategy.

Third, in view of the nature of limited edition products, enterprises produce and supply only a small quantity of them in the market. However, some business-type resellers tend to practice cornering and hoarding to monopolize products and maximize premiums. In the case of offline drawing, part-timers are used in general. Even back-door deals are increasing in conspiracy with a person in charge at the enterprise. Recently, online raffles have been increasing due to COVID-19, and, in this case as well, a small number of consumers increasingly monopolize limited edition products by using a "bot." Enterprises need to gain and maintain trust from consumers by addressing such issues. If a business is satisfied merely with raising a sustainable marketing issue, its brand image can be damaged seriously.

Finally, it is necessary for enterprises to share with consumers released information on a reselling platform and limited edition products of scarcity in order to satisfy their cognitive need. While most enterprises give notice on a product release schedule only through a certain information channel, this direction may involve problems if information is monopolized and fails to be delivered to common 
consumers. Marketing and brand vitalization based on customer reselling needs a sustainable customer relationship and collaboration strategy. In these backgrounds, companies should consider information sharing platforms with consumers and market stake-holders.

\subsection{Research limitations and Future Plan}

However, this study has its limitation in that its survey was conducted among resellers with considerable experience in the Korean market. Thus, it is difficult to generalize the findings of this study, and future studies need to include resellers who are professional and active in the global market in order to address this limitation. In addition, the survey as part of this study was conducted among resellers acting mainly over the fashion market since the reselling of limited edition products focused on this particular market. Therefore, marketing on limited edition products is currently strengthening in various areas, and conditions of reselling and affecting factors may be varied depending on product types. Hence, future studies could examine differences depending on product types and industry sectors more specifically and comparatively. In addition to those, this study presents its definitions of affecting factors and results of importance analysis on the basis of the AHP methodology. Future researches may include complementary empirical research on how such factors, which were derived in this study, affect reselling or satisfaction among consumers in reality.

Author Contributions: Funding acquisition, W.K.; methodology, B.K.; resources, W.K.; supervision, B.K.; writing-original draft, B.K. and W.K.; writing-review and editing, B.K. All authors have read and agreed to the published version of the manuscript.

Funding: This research received no external funding.

Acknowledgments: This research was supported by aSSIST (Seoul School of Integrated Sciences and Technologies).

Conflicts of Interest: The authors declare no conflict of interest.

\section{References}

1. Welch, L. This Startup is Bringing the \$25 Billion Thrift Shop Market to Your Doorstep; Inc. magazine: New York, NY, USA, 2020; Available online: https://www.inc.com/magazine/201607/liz-welch/thredup-reinventingthrift-store.html (accessed on 23 June 2020).

2. Zhang, L. Fashioning the feminine self in prosumer capitalism: Women's work and the transnational reselling of Western luxury online. J. Consum. Cult. 2017, 17. [CrossRef]

3. Li, Q.; Wang, Q.S.; Song, P.J. The effects of agency selling on reselling on hybrid retail platforms. Int. J. Electron. Commer. 2019, 23, 524-556. [CrossRef]

4. Libai, B.; Bolton, B.; Bügel, M.S.; Ruyter, K.; Götz, O.; Risselada, H.; Stephen, A.T. Cstomer-to-customer interactions: Broadening the scope of word of mouth research. J. Serv. Res. 2010, 13, 267-292. [CrossRef]

5. Chu, H.; Liao, S. Toward a conceptual model of consumer online resale behavior: An exploratory study in Taiwan. J. Internet Commer. 2008, 7, 220-252. [CrossRef]

6. Chu, H.; Liao, S. Exploring consumer resale behavior in $\mathrm{C} 2 \mathrm{C}$ online auctions: Taxonomy and influence on consumer decisions. Acad. Mark. Sci. Rev. 2007, 11, 1-25.

7. Finch, B.J. Customer expectations in online auction environments: An exploratory study of customer feedback and risk. J. Oper. Manag. 2007, 25, 985-997. [CrossRef]

8. Li, D.; Li, J.; Lin, Z. Online consumer-to-consumer market in China: A comparative study of Taobao and eBay. Electron. Commer. Res. Appl. 2008, 7, 55-67. [CrossRef]

9. Swami, S.; Khairnar, P.J. Optimal normative policies for marketing of products with limited availability. Ann. Oper. Res. 2006, 143, 107-121. [CrossRef]

10. Van Bove, L.; Gilovich, T. To do or to have? That is the question. J. Personal. Soc. Psychol. 2003, 85, 1193-1202. [CrossRef]

11. Jang, W.S.; Ko, Y.J.; Morris, J.D.; Chang, Y.H. Scarcity message effects on consumption behavior: Limited edition product considerations. Psychol. Mark. 2015, 32, 989-1001. [CrossRef]

12. Zhang, S.; Zhang, J.X. Agency selling or reselling: E-tailer information sharing with supplier offline entry. Eur. J. Oper. Res. 2020, 280, 134-151. [CrossRef] 
13. Murphy, S.L. Consumers as resellers: Exploring the entrepreneurial mind of north American consumers reselling online. Int. J. Bus. Inf. 2015, 14, 183-224.

14. Anwar, S.; McMillian, R.; Zheng, M. Bidding behavior in competing auctions: Evidence from eBay. Eur. Econ. Rev. 2006, 50, 307-322. [CrossRef]

15. Lin, Z.; Li, D.; Janamanchi, B.B.; Huang, W. Reputation distribution and consumer-to-consumer online auction market structure: An exploratory study. Decis. Support Syst. 2006, 41, 435-448. [CrossRef]

16. Brannon, L.A.; Brock, T.C. Limiting time for responding enhances behavior corresponding to the merits of compliance appeals: Refutations of heuristic-cue theory in service and consumer settings. J. Consum. Psychol. 2001, 10, 135-146. [CrossRef]

17. Aggarwal, P.; Jun, S.Y.; Huh, J.H. Scarcity messages: A consumer competition perspective. J. Advert. 2011, 40, 19-30. [CrossRef]

18. Sotgiu, F.; Ancarani, F. The drivers of e-tailers' price levels. Int. Rev. Retail. Consum. Res. 2005, 15, 75-89. [CrossRef]

19. Cheema, A.; Kaikati, A.M. The effect of need for uniqueness on word of mouth. J. Mark. Res. 2010, 47, 553-563. [CrossRef]

20. Abhishek, V.; Jerath, K.; Zhang, Z.J. Agency selling or reselling? Channel structures in electronic retailing. Manag. Sci. 2016, 62, 2149-2455. [CrossRef]

21. Amaldoss, W.; Jain, S. Pricing of conspicuous goods: A competitive analysis of social effects. J. Mark. Res. 2005, 42, 30-42. [CrossRef]

22. Dhar, R.; Wertenbroch, K. Consumer choice between hedonic and utilitarian goods. J. Mark. Res. 2000, 37, 60-71. [CrossRef]

23. Ku, H.H.; Kuo, C.C.; Kuo, T.W. The effect of scarcity on the purchase intentions of prevention and promotion motivated consumers. Psychol. Mark. 2012, 29, 541-548. [CrossRef]

24. Eisend, M. Explaining the impact of scarcity appeals in advertising: The mediating role of perceptions of susceptibility. J. Advert. 2008, 37, 33-40. [CrossRef]

25. Bamberg, S. How does environmental concern influence specific environmentally related behaviors? A new answer to an old question. J. Environ. Psychol. 2003, 23, 21-32. [CrossRef]

26. Tian, K.T.; Bearden, O.W.; Hunter, L.G. Consumers need for uniqueness: Scale development and validation. J. Consum. Res. 2001, 28, 50-66. [CrossRef]

27. Leary, R.B.; Vann, R.J.; Mittelstaedt, J.D.; Murphy, P.E.; Sherry, F.J. Changing the marketplace one behavior at a time: Perceived marketplace influence and sustainable consumption. J. Bus. Res. 2014, 67, 1953-1958. [CrossRef]

28. Sharma, P.; Roy, R. Looking beyond first-person effects (FPEs) in the influence of scarcity appeals in advertising: A replication and extension of Eisend. J. Advert. 2016, 45, 78-84. [CrossRef]

29. Carrington, M.J.; Neville, B.A.; Whitwell, G.J. Lost in translation: Exploring the ethical consumer intention behavior gap. J. Bus. Res. 2014, 67, 2759-2767. [CrossRef]

30. Gracia, A.; de Magistris, T. Organic food product purchase behaviour: A pilot study for urban consumers in the South of Italy. Span. J. Agric. Res. 2013, 5, 439-451. [CrossRef]

31. Amaldoss, W.; Jain, S. Conspicuous consumption and sophisticated thinking. Manag. Sci. 2005, 51, $1449-1466$. [CrossRef]

32. Chen, H.; Sun, T. Clarifying the impact of product scarcity and perceived uniqueness in buyers' purchase behavior of game of limited-amount version. Asia Pac. J. Mark. Logist. 2014, 26, 232-249. [CrossRef]

33. Gierl, H.; Huettl, V. Are scarce products always more attractive? The interaction of different types of scarcity signals with products' suitability for conspicuous consumption. Int. J. Res. Mark. 2010, 27, 225-235. [CrossRef]

34. Gierl, H.; Plantsch, M.; Schweidler, J. Scarcity effect on sales volume in retail. Int. Rev. Retail. Consum. Res. 2008, 18, 45-61. [CrossRef]

35. Berger, J.; Heath, C. Who drives divergence? Identity signaling, outgroup dissimilarity, and the abandonment of cultural tastes. J. Personal. Soc. Psychol. 2008, 95, 593-607. [CrossRef]

36. Brand, R.R.; Cronin, J.J. Consumer-specific determinants of the size of retail choice sets: An empirical comparison of physical good and service providers. J. Serv. Mark. 1997, 11, 19-38. [CrossRef]

37. Han, Y.J.; Nunes, J.C.; Drèze, X. Signaling status with luxury goods: The role of brand prominence. J. Mark. 2010, 74, 15-30. [CrossRef] 
38. Alpert, F.H.; Kamins, M.A.; Graham, J.L. An examination of reseller buyer attitudes toward order of brand entry. J. Mark. 1992, 56. [CrossRef]

39. Ku, H.; Kuo, C.; Fang, W.; Yu, Y. The impact of retail out-of-stock options on preferences: The role of consumers' desire for assimilation versus differentiation. Mark. Lett. 2014, 25, 53-66. [CrossRef]

40. Jones, M.A.; Taylor, V.A.; Reynolds, K.E. The effect of requests for positive evaluations on customer satisfaction ratings. Psychol. Mark. 2014, 3, 161-170. [CrossRef]

41. Byun, S.; Sternquist, B. Here Today, gone tomorrow: Consumer reactions to perceived limited availability. J. Mark. Theory Pract. 2012, 20, 223-234. [CrossRef]

42. Suri, R.; Kohli, C.; Monroe, K.B. The effects of perceived scarcity on consumers' processing of price information. J. Acad. Mark. Sci. 2007, 35, 89-100. [CrossRef]

43. Rajat, R.; Sharma, P. Scarcity appeal in advertising: Exploring the moderating roles of need for uniqueness and message framing. J. Advert. 2015, 44, 349-359.

44. Ruvio, A.; Shoham, A.; Brencic, M.M. Consumers' need for uniqueness: Short- form scale development and cross-cultural validation. Int. Mark. Rev. 2008, 25, 33-53. [CrossRef]

45. Simonson, I.; Nowlis, M.S. The role of explanations and need for uniqueness in consumer decision making: Unconventional choices based on reasons. J. Consum. Res. 2000, 27, 49-68. [CrossRef]

46. Sundie, J.M.; Kenrick, D.T.; Griskevicius, V.; Tybur, J.M.; Vohs, K.D.; Beal, D.J. Peacocks, Porsches, and Thorstein Veblen: Conspicuous consumption as a sexual signaling system. J. Personal. Soc. Psychol. 2011, 100, 664-680. [CrossRef] [PubMed]

47. Wu, W.; Lu, H.; Wu, Y.; Fu, C. The effects of product scarcity and consumers' need for uniqueness on purchase intention. Int. J. Consum. Stud. 2012, 36, 263-274. [CrossRef]

48. Zhu, R.; Argo, J.J. Exploring the impact of various shaped seating arrangement on persuasion. J. Consum. Res. 2013, 40, 336-349. [CrossRef]

49. Jung, J.M.; Kellaris, J.J. Cross-national differences in proneness to scarcity effects: The moderating roles of familiarity, uncertainty avoidance, and need for cognitive closure. Psychol. Mark. 2004, 21, 739-753. [CrossRef]

50. Suri, R.; Monroe, K.B. The effects of time constraints on consumers' judgments of prices and products. J. Consum. Res. 2003, 30, 92-104. [CrossRef]

51. Reynolds, K.E.; Gilkeson, J.H.; Niedrich, R.W. The influence of seller strategy on the winning price in online auctions: Amoderated mediation model. J. Bus. Res. 2009, 62, 22-30. [CrossRef]

52. Guiot, D.; Roux, D. Author's personal copy a second-hand shoppers' motivation scale: Antecedents, consequences, and implications for retailers. J. Retail. 2010, 86, 383-399. [CrossRef]

53. Liao, S.; Chu, H. Influence of consumer online resale awareness on purchase decisions: A mental accounting perspective. Eur. J. Mark. 2013, 47, 1576-1597. [CrossRef]

54. Liu, X.; Burns, A.C.; Hou, Y. Comparing online and in-store shopping behavior towards luxury goods. Int. J. Retail. Distrib. Manag. 2013, 41, 885-900. [CrossRef]

55. Simpson, P.M.; Siguaw, J.A.; Baker, T.L. A model of value creation: Supplier behaviors and their impact on reseller-perceived value. Ind. Mark. Manag. 2001, 30, 119-134. [CrossRef]

56. Effron, D.A.; Miller, D.T. Diffusion of entitlement: An inhibitory effect of scarcity on consumption. J. Exp. Soc. Psychol. 2011, 47, 378-383. [CrossRef]

57. Subramanian, B.; Stock, A. Limited edition products: When and when not to offer them. Mark. Sci. 2009, 28, 336-355.

58. Miyazaki, A.D.; Stanaland, A.J.; Lwin, M.O. Self-regulatory safeguards and the online privacy of preteen children. J. Advert. 2009, 38, 79-91. [CrossRef]

59. Christ, P. Segmenting reseller markets: A multi-level approach. J. Segm. Mark. 1997, 1, 75-94. [CrossRef]

60. Swaminathan, V.; Page, K.L.; Gurhan-Canli, Z. My brand or our brand: The effects of brand relationship dimensions and self-construal on brand evaluations. J. Consum. Res. 2007, 34, 248-259. [CrossRef]

61. Ramzi, E.H.; Weerakkody, V.; Osmani, M.; Thakker, D.; Kapoor, K.K. Examining citizens' perceived value of internet of things technologies in facilitating public sector services engagement. Gov. Inf. Q. 2019, 36, 310-320.

62. Sinha, S.K.; Verma, P. Impact of sales promotion's benefits on perceived value: Does product category moderate the results. J. Retail. Consum. Serv. 2020, 52, 101887. [CrossRef] 
63. Gallarza, M.G.; Saura, I.G. Value dimensions, perceived value, satisfaction and loyalty: An investigation of university students' travel behavior. Tour. Manag. 2006, 27, 437-452. [CrossRef]

64. Hollebeek, L. Individual-level cultural consumer engagement styles: Conceptualization, propositions and implications. Int. Mark. Rev. 2018, 35, 42-71. [CrossRef]

65. Soscia, I. Gratitude, delight or guilt: The role of consumers emotions in predicting post-consumption behaviors. Psychol. Mark. 2007, 24, 871-894. [CrossRef]

66. Yuan, Y.H.; Wu, C. Relationships among experiential marketing, experiential value and customer satisfaction. J. Hosp. Tour. Res. 2008, 32, 387-408. [CrossRef]

67. Tsai, C.F. The relationships among theatrical components, experiential value, relationship quality, and relationship marketing outcomes. Asia Pac. J. Tour. Res. 2015, 20, 897-919. [CrossRef]

68. Van Doorn, J.; Lemon, K.N.; Mittal, V.; Nass, S.; Pick, D.; Pirner, P.; Verhoef, P.C. Customer engagement behavior, theoretical foundations and research directions. J. Serv. Res. 2010, 13, 253-266. [CrossRef]

69. Alanazi, E.; Mouhoub, E.; Mohammed, B. A preference aware Interactive system for online shopping. Comput. Inf. Sci. 2012, 5, 33-42. [CrossRef]

70. Yang, J.; Hu, X.; Zhang, H. Effects of a reputation feedback system on an online consumer-to-consumer auction market. Decis. Support Syst. 2007, 44, 93-104. [CrossRef]

71. Gopal, R.D.; Pathak, B.; Tripathi, A.K.; Yin, F. From fatwallet to eBay: An investigation of online deal-forums and sales promotions. J. Retail. 2006, 82, 155-164. [CrossRef]

72. Ahn, I.S.; Kim, S.H.; Kim, M.Y. The relative importance of values, social norms, and enjoyment-based motivation in explaining pro-environmental product purchasing behavior in apparel domain. Sustainability 2020, 12, 6797. [CrossRef]

73. Becker-Olsen, K.L.; Cudmore, B.A.; Hill, R.P. The impact of perceived corporate social responsibility on consumer behavior. J. Bus. Res. 2006, 59, 46-53. [CrossRef]

74. Van Laarhoven, P.; Pedrycz, W. A fuzzy extension of Saaty's priority theory. Fuzzy Sets Syst. 1983, 11, $229-241$. [CrossRef]

75. Wu, H.D. Systemic determinants of international news coverage: A comparison of 38 countries. J. Commun. 2000, 20, 110-130. [CrossRef]

76. Ngai, E. Selection of web sites for online advertising using the AHP. Inf. Manag. 2003, 40, 233-242. [CrossRef]

77. Saaty, T.L. The Analytic Hierarchy Process: Planning. Priority Setting. Resource Allocation; MacGraw-Hill: New York, NY, USA; International Book Company: New York, NY, USA, 1980.

78. Sadeghpour, F.; Far, M.G.; Khah, A.R.; Amiri, M.A.A. Marketing strategic planning and choosing the right strategy using AHP technique. Douth J. Financ. Manag. 2017, 1, 45-51.

79. Liu, D.R.; Shih, Y.Y. Integrating AHP and data mining for product recommendation based on customer lifetime value. Inf. Manag. 2005, 42, 387-400. [CrossRef]

80. Chan, L.K.; Kao, H.P.; Wu, M.L. Rating the importance of customer needs in quality function deployment by fuzzy and entropy methods. Int. J. Prod. Res. 1999, 37, 2499-2518. [CrossRef]

81. Kabir, G.; Hasin, M. Evaluation of costumer oriented success factors in mobile commerce using fuzzy AHP. J. Ind. Eng. Manag. 2011, 4, 361-386.

82. Kumar, A.; Shankar, R.; Debnath, R.M. Analyzing customer preferene and measuring relative efficiency in telecom sector: A hybrid fuzzy AHP/DEA study. Telemat. Inform. 2015, 32, 447-462. [CrossRef]

83. Yang, C.; Huang, J.B. A decision model for IS outsourcing. Intern. J. Inf. Manag. 2000, 20, 225-239. [CrossRef]

84. Yoo, S.K.; Kim, B.Y. The effective factors of cloud computing adoption success in organization. J. Asia Financ. Econ. Bus. 2019, 6, 215-227. [CrossRef]

85. Helm, S.; Subramaniam, B. Exploring socio-cognitive mindfulness in the context of sustainable consumption. Sustainability 2019, 11, 3692. [CrossRef]

86. Chen, X.; Fang, S.; Li, Y.; Wang, H. Does identification influence continuous e-commerce consumption? The mediating role of intrinsic motivations. Sustainability 2019, 11, 1944. [CrossRef]

(C) 2020 by the authors. Licensee MDPI, Basel, Switzerland. This article is an open access article distributed under the terms and conditions of the Creative Commons Attribution (CC BY) license (http://creativecommons.org/licenses/by/4.0/). 